\author{
Siniša Vilke \\ University of Rijeka, Faculty of Maritime Studies, Studentska 2, 51000 Rijeka, Croatia \\ Ines Ostović \\ Rijeka International Airport, Hamec 1, 51513 Omišalj, Croatia
}

\title{
Sustainability and New Technologies in Urban Transport and Mobility
}

\begin{abstract}
In this article the energy efficiency in urban transport is analysed the implementation of which would result in the reduction of energy consumption and of carbon dioxide and other greenhouse gas emissions and would thus ensure the urban transport system sustainability. Nowadays the relations of urban transport and IT solutions as well as the impact of urban transport on the community and environment are extensive. The integration of information flow in the decision making process related to the modern transport and urban mobility has to be brought to a higher level. The main goal is to upgrade the quality of life in the urban environment by improving intelligent transport systems, implementing new technologies and promoting the sustainable development. In the article the possibilities of urban transport improvement according to modern requirements of sustainability policy and environmental management are analysed.

The aim of the paper is to point to unfavourable effects produced by the urban transport upon the sustainable development and mobility and to emphasize the significance of measures aimed at reaching sustainability and energy efficiency with particular emphasis on the implementation of new technologies and alternative fuels.
\end{abstract}

Key words: sustainable development, intelligent transport systems, alternative fuels, urban transport

\section{Introduction}

Smart specialization and the associated strategy by which the European Union, along with its members, has opted for economic growth, is described as smart and viable, and smart cities are just as a segment of overall development planned in that strategy. The strategic framework is designed at an international level and its application will largely depend on the readiness of local authorities to make concessions in classical thinking and provide space for modern-day development and innovation. Smart specialization is a new concept of innovation policy structured in order to promote effective and efficient use of public investment in research and 
development. Its goal is to stimulate innovation in order to achieve economic growth and prosperity by enabling countries / regions to focus on their own strengths.

A smart specialization strategy as a thematic priority area within "Energy and Sustainable Environment" and "Energy Technology, Systems and Equipment" as the sub-thematic priority area, is one of the major research and development topics (IRIs) that includes smart cities. In the strategy, smart cities are recognized as one of the key areas in the process of entrepreneurial growth, placing them in the same category with smart networks and smart advanced utility services.

Sustainable development is an individual framework for any consumer or state that achieves individual environmental and natural resource targets that are of significant importance to future generations. The goals of such development are known as the pillars of sustainable development that represent the correlative relationship between environmental protection, social responsibility and economic efficiency. These goals are universal in all countries of the world and must be applied by all mankind. In their implementation, consideration is given to specific opportunities, possibilities and conditions that can be found in different world regions. It is also necessary to identify priority areas of action and view one's own potentials that contribute to sustainable development around the world.

Mobility means the ease of movement of goods and services with affordable and safe means of transport that must be available at lower social, environmental and economic costs. The aim is to optimally use materials, energy and information in intelligent and efficient ways to reduce the impact of urban and interurban traffic on the environment while satisfying both local and global mobility needs. Using sustainable, safe and high-quality means reduces congestion in urban areas, leading to improved passenger mobility, but also to lower costs, time savings, improved accessibility and better health of the population and ecosystems. Having in mind that today more than $50 \%$ of the world's population (EU> $80 \%$ ) live in cities or urban areas, moving to urban sustainability requires a new culture of cities and spatial planning [1].

Urban transport encompasses all types of public and private transport intended for human transport and transport of goods within urban traffic. As cities are growing increasingly and traffic hubs are getting bigger, states are looking for alternative solutions to encourage private transit to public transport. The light rail, tram and metro system, as well as the Bus Rapid Transit (BRT), represents an alternative to individual transport [2].

Intelligent transport systems (ITS) are modern and complex systems that enhance driving experience. These systems include communication through a complex backup system of various subjects and facilities in traffic, such as vehicles themselves, drivers, passengers, road operators and the environment. These systems contribute to the improvement of elements such as reducing crowd, increasing traffic flow in urban environments, improving vehicle efficiency, reducing environmental pollution while generally increasing safety in traffic is highlighted as the umbrella foundation of the system. 


\section{Smart Specialization and Smart Cities in the Context of Sustainable Development}

The idea of smart specialization has emerged from the EU Commission Report 2009 , released by a group of independent experts, and the report alone gave the answer that knowledge can help raise standards and achieve a knowledge society that will enable sustainable development. Smart specialization means identifying the unique features and resources of each country and region, highlighting the competitive advantages of a particular region and gathering regional stakeholders and resources around their vision of excellence-based future [3].

The development of the region for which smart specialization is adopted plays a major role in choosing a strategic vision through smart specialization and encompasses a variety of instruments such as establishing an effective innovation system, infrastructure development and research, development and innovation, global value chain upgrades and promoting the internationalization of the economy of individual EU countries and finally the smart skills development.

The use of Machine-to-Machine (M2M) technology to connect devices in the context of the Internet of Things (IOT) to city infrastructure as a basis for successful realization of smart cities requires a central remote monitoring, analysis and management platform based on acquired data. The same platform facilitates the exchange of data and information between the provider and the service user.

The main goal of the smart specialization strategy is to achieve sustainable and smart growth with the goal of overall economic development through research, innovation and knowledge society as a response to economic and traffic issues of today.

Sustainable development can be described as a process of achieving a balance between economic, social and environmental demands in order to meet the needs of the present population without compromising the ability of future populations to meet their living needs. Sustainable development is the socio-ecological process characterized by meeting human needs while maintaining the quality of the natural environment [8]. It consists of three components: economic sustainability, ecological sustainability and socio-political sustainability. Thus, it represents a framework for designing policies and strategies of continuous economic and social development without negative consequences for the environment and natural resources to be preserved for the advancement of human activities in the future.

In the smart specialization strategy, smart cities are recognized as one of the key areas in the process of entrepreneurial growth that puts them in the same category with smart networks and smart advanced utility services. Instead of following the top-tobottom approach, primarily including the public sector, the process of developing a smart specialization strategy should follow a bottom-up approach and identify one's own strengths and competitive advantages through the collaboration and joint efforts 
of the public, scientific-research and business sectors and through the entrepreneurial discovery process. In the process of smart specialization, structural changes can be promoted through modernization, diversification, transition or radical change in all EU member states.

The smart city is defined as the environment that uses ICT - information and communication technologies to improve the quality of life and standards of its citizens. Such a city contributes to the efficiency, availability and quality of public services and to the growth of competitiveness, ensuring the needs of current and future generations from the perspective of sustainable development of the economy and society, the exploitation of limited resources and the preservation of the environment.

Smart cities focus on six dimensions of development, namely smart living, smart economy, smart people, smart environment, smart governance, and smart mobility. In order to facilitate and enable communication between these six dimensions, technical standards should be introduced in terms of communication, telecommunications, information technology and electronics.

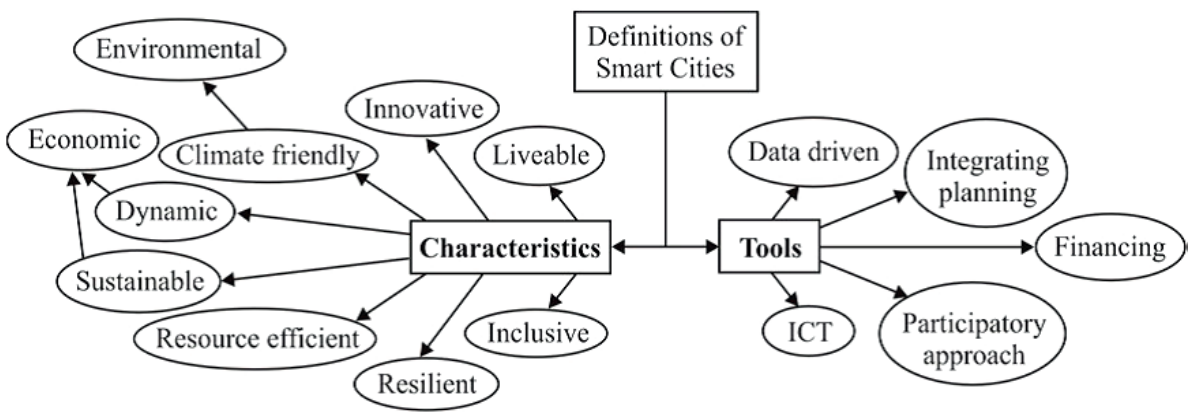

Figure 1-Characteristics and tools used to define the Smart City [4]

Smart specialization and associated strategy by which the European Union, along with its members, has opted for economic growth, is described as smart and viable, and smart cities are just as a segment of overall development planned in that strategy. The strategic framework is designed at the international level, and its implementation will largely depend on the readiness of local authorities to make concessions in classical thinking and provide space for development and innovation of the contemporary form. Smart specialization is a new concept of innovation policy structured in order to promote effective and efficient use of public investment in research and development. Its goal is to stimulate innovation in order to achieve economic growth and prosperity by enabling countries / regions to focus on their own strengths. 


\section{External Traffic Effects on Sustainable Development}

The increase in the exchange of goods and services of regional and national economies "results" in the continuous growth of the world economy, which implies the need to improve the transport system. The development of traffic depends on the development of the economy as a whole, despite the regional differences and the different development of certain types of traffic. Since the 1970s, demand for developed traffic has grown steadily as well as the GDP of some countries.

Table 1 - Breakdown of traffic industry in the economic life of $R C$

\begin{tabular}{|l|l|}
\hline GDP 2017 & $\begin{array}{l}\text { GDP total amounts to 365.643 } \\
\text { million HRK, i.e. 87.900 HRK per } \\
\text { capita }\end{array}$ \\
\hline Employment & $\begin{array}{l}1.181 .418 \text { employed in 2017 (in } \\
\text { traffic sector 62.089) }\end{array}$ \\
\hline $\begin{array}{l}\text { Goods traffic (maritime and coastal, } \\
\text { road, rail, internal navigable } \\
\text { waterways, piping) 2017 }\end{array}$ & $\begin{array}{l}\text { Traffic accounts for 125 billion tkm* } \\
\text { (of which maritime and coastal } \\
86.1 \% \text {, road 9.4\% and rail 2\%). }\end{array}$ \\
\hline $\begin{array}{l}\text { Passenger traffic (road, air, rail, } \\
\text { maritime and coastal) 2017 }\end{array}$ & $\begin{array}{l}\text { Traffic accounts for about 7.2 billion } \\
\text { pkm* (of which road 57\%, air 23\%, } \\
\text { rail 10.2\% and maritime and coastal } \\
\text { 9.6\%). }\end{array}$ \\
\hline Safety 2017 & $\begin{array}{l}\text { Roads: 331 lives lost, compared to } \\
\text { more than 500 in 2008 and 2009 }\end{array}$ \\
\hline Environmental impact 2016 & $\begin{array}{l}\text { Owing to increased use of vehicles } \\
\text { with catalytic converters, gas } \\
\text { emissions were significantly reduced } \\
\text { in the period 2003 - 2016: NOx } \\
\text { (32\%), CO (73\%), Pb (93\%) }\end{array}$ \\
\hline
\end{tabular}

Source: Authors according to [6]

* tkm-tonnes per km; pkm-passengers per $\mathrm{km}$

According to data from Table 1, the total gross domestic product in the Republic of Croatia in 2017 amounted to HRK 365.5 million i.e. about HRK 87,900 per capita. It is also clear from the table that a part of the employed in the transport sector amounted to $5.2 \%$ of the total number of employed persons in the Republic of Croatia in 2017. Analyzing the turnover of goods by the transport branch, it is apparent that 
the maritime traffic accounts for approximately $86 \%$ of total traffic, road traffic for slightly more than $9 \%$ and rail for $2 \%$. As for passenger traffic, it is noticed that road traffic accounts for a share of approximately $57 \%$ of total traffic, air traffic for $23 \%$, and rail and sea traffic for around $10 \%$. It should be noted that the road traffic, including both public passenger transport and private transport, is the dominant mode of transport in the urban traffic of the largest city centres in the Republic of Croatia.

Sustainable transport development depends first and foremost on developing and building a transport infrastructure that contributes to the country's economic competitiveness, reduces its traffic isolation by allowing balanced regional development and creating conditions for the development of sustainable mobility. The main goal of developing a country's transport system is to enable good connections between all parts of its territory and between the islands and the mainland in order for all economic, social and environmental needs to be satisfied while minimizing its negative impact on the economy, the environment and the whole society. That is to say that, on the one hand, traffic is extremely important for the economic development of every society, but on the other hand it is necessary to minimize its adverse effects on space and the environment, taking into account sustainable mobility and future development.

Table 2 - Energy consumption in the Republic of Croatia by the energy type $2007-2016$ PJ* $^{*}$

\begin{tabular}{|l|c|c|c|c|c|c|c|c|c|c|}
\hline $\begin{array}{l}\text { Energy } \\
\text { type }\end{array}$ & 2007 & 200 & 2009 & 2010 & 2011 & 2012 & 2013 & 2014 & 2015 & 2016 \\
\hline Coal & 33.74 & 34.65 & 24.66 & 30.92 & 31.66 & 28.37 & 32.18 & 31.59 & 29.86 & 32.14 \\
\hline Firewood & 44.15 & 47.10 & 48.93 & 52.29 & 51.50 & 52.10 & 51.67 & 46.12 & 52.69 & 52.47 \\
\hline Liquid fuel & 189.70 & 180.15 & 178.04 & 152.54 & 149.30 & 134.17 & 128.37 & 125.80 & 130.92 & 130.78 \\
\hline $\begin{array}{l}\text { Natural } \\
\text { gas }\end{array}$ & 114.22 & 110.22 & 102.15 & 111.37 & 108.60 & 101.78 & 95.54 & 84.62 & 87.16 & 91.08 \\
\hline $\begin{array}{l}\text { Water } \\
\text { power }\end{array}$ & 46.66 & 55.51 & 72.32 & 87.24 & 47.58 & 47.32 & 84.92 & 88.99 & 61.63 & 65.63 \\
\hline $\begin{array}{l}\text { Electrical } \\
\text { power }\end{array}$ & 21.23 & 21.64 & 18.01 & 14.28 & 25.76 & 26.75 & 13.93 & 14.23 & 24.44 & 19.91 \\
\hline $\begin{array}{l}\text { Thermal } \\
\text { pumps }\end{array}$ & 0.37 & 0.45 & 0.54 & 0.63 & 0.60 & 0.61 & 0.63 & 0.52 & 0.62 & 0.66 \\
\hline $\begin{array}{l}\text { Other } \\
\text { renewable- } \\
\text { sources }\end{array}$ & 0.80 & 0.95 & 1.39 & 2.24 & 2.72 & 5.59 & 7.65 & 10.35 & 11.16 & 12.98 \\
\hline Total & 453.88 & 450.69 & 446.05 & 451.50 & 417.71 & 396.69 & 414.89 & 402.22 & 396.48 & 405.34 \\
\hline
\end{tabular}

Source: Authors according to [6]

*PJ stands for petajoule and 49.59 PJ equals $49.59 \times 10^{15}$ joules 
The demand for traffic in urban areas has been growing increasingly, with adverse effects on the environment and the quality of life in general. With regard to urban traffic, in addition to a number of positive effects of traffic for the development of the city, traffic in the last decades has led to a number of negative impacts, among which we would highlight traffic jams, low speeds and environmental pollution that lead to increased costs. In addition, one of the significant external effects of traffic, especially the road traffic, is the safety of all participants including pedestrians. Efficiency and quality of traffic in cities and mobility of people in urban environments are increasingly threatened.

In addition to traffic jams identified as the leading disadvantage of traffic in cities, there are other issues such as reduced traffic safety, traffic noise, peak loads in urban centres, limited availability and mobility, and a negative impact on space and the environment... Traffic is generally responsible for a significant share in total air pollution, and about $80 \%$ of traffic pollution is caused by road traffic, which is particularly negative in cities.

The analysis of the data presented in Table 2 shows data on total energy consumption in the Republic of Croatia that are compiled on the basis of data obtained from statistical surveys conducted by the Central Bureau of Statistics, research by the Energy Institute "Hrvoje Požar" (EIHP) and from administrative sources and estimates of EIHP. In total energy consumption in 2016 there is a drop in energy consumption of 48.54 PJ compared to 2007 Liquid fuels and natural gas account for the highest share in energy consumption while the lowest share refers to heat pumps.

2007

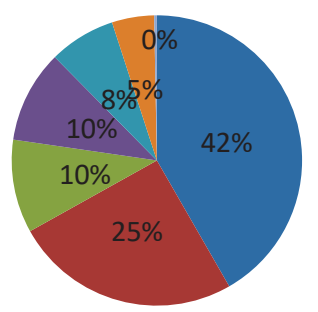

- liquid fuel

natural gas

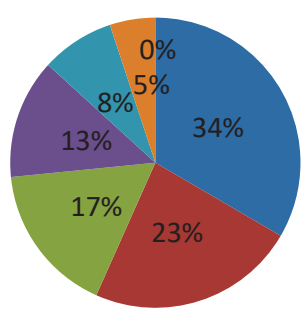

natural gas

Graph 1 - Structure of total energy consumption in RC in 2007 and 2016 Source: Authors according to [6]

Graph 1 shows the difference between total energy consumption in the Republic of Croatia in 2007 and 2016. Thus, the consumption of liquid fuel in 2016 is lower by $8 \%$ and natural gas by $2 \%$ compared to 2007 . Energy consumption of firewood in this period recorded a slight increase of $6 \%$, water power by $3 \%$ and coal by $1 \%$. The amount of electrical power used in 2006 and 2017 is practically unchanged, while it 
is important to point out that the consumption of renewable energy in the observed period was increased by $5 \%$.

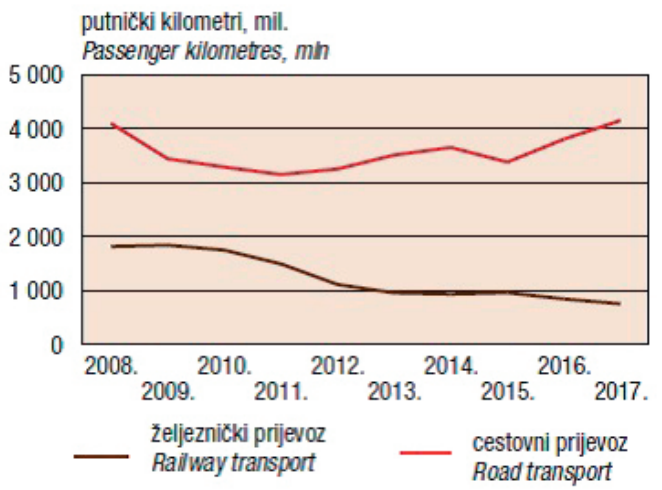

Figure 2 - Land passenger transport in RC by the type 2008 - 2017, in pkm [6]

According to the data of the Central Bureau of Statistics, as presented in Figure 2 , the road transport of passengers has risen in the last 3 years to slightly exceed 4 million passenger kilometres in 2017. On the other hand, passenger rail transport has been falling in the last 3 years and in 2017 it accounted for less than a million passenger $\mathrm{km}$, i.e. below the road transport by more than 3 million.

\section{Effects of Energy Efficiency on Sustainability and Urban Traffic}

Road transport is the main branch of cargo transport and encompasses most of the land transport in the European Union. Air pollution from road vehicles is a significant problem since noxious exhaust gases from road vehicles are one of the most influential factors in environmental pollution in general. This is particularly apparent in developed cities where the high concentration of personal cars and public transport buses is present. Although motor vehicle driving technology is constantly evolving and vehicles are more and more powered by alternative fuels, the number of vehicles is growing rapidly and the emission of harmful exhaust gases is constantly increasing, especially in urban environments.

Of the total world energy consumption, the European Union uses about $30 \%$ and is responsible for $25 \%$ of greenhouse gas emissions, of which $71.3 \%$ refers to road traffic [11].

Road vehicles are subject to increasing environmental requirements, particularly concerning CO, CxHy, NOx and particles. The Regulations of the Economic 
Commission and the United Nations for Europe (ECE Regulations) provide for the emission standards for certain exhaust gases to be met by road vehicles [12].

Having in mind the EU targets for reducing greenhouse gas emissions and the increasing air pollution, particular attention should be paid to the environment friendly transport, i.e. to energy efficiency in transport and to encourage projects to increase the energy efficiency of transport systems. For this purpose, it is important to encourage the use of alternative fuel vehicles and those with lower $\mathrm{CO}_{2}$ emissions and other harmful exhaust gases and introduce new technologies using modern ITS solutions.

\section{Legal Regulations for Energy Saving and Reduction of Harmful Exhaust Gas Emissions}

The basic act that determines the energy policy and plans for energy supply development of the Republic of Croatia until 2030 was adopted in 2002 as the Energy Development Strategy of the Republic of Croatia (NN 38/2002). In 2005, the Republic of Croatia signed the Energy Community Treaty, which came into force at the end of 2007. The said Treaty defines the objectives of the Energy Community, which include: establishment of conditions for the development of an energy market in a single regulatory space, improvement of the environmental state by increasing energy efficiency and larger use of renewable energy sources and increasing the security of energy supply.

The Republic of Croatia ratified the Kyoto Protocol in 2007. Croatia was acknowledged as the special circumstances in which it was found in 1990 since it had used, as a constituent part of Yugoslavia, the energy of thermal power plants located outside Croatia, i.e. in B \& H and Serbia. For this reason, additional greenhouse gas emissions of 3.5 million tonnes were granted to the Republic of Croatia in the circumstances of creation of the state. The quota was an addition to the previous one of 31.12 million tonnes so that the total quota in 1990 amounted 34.62 million tonnes [13].

In 2008, the European Union launched the initiative of the Covenant of Mayors that was later extended to the rest of the world and today it includes 7,755 cities in 53 countries around the world. The Covenant of Mayor implies the inclusion of local government and its citizens in the implementation of specific energy efficiency measures to reduce $\mathrm{CO}_{2}$ emissions within their city either by $20 \%$ by 2020 or by $40 \%$ by 2030 [14]. The obligation stemming from the above mentioned initiative is the development of a Sustainable Energy Action Plan (SEAP) for the signatory cities to be submitted to the European Commission within one year. Efforts to reduce the impact of cities on climate change have been recognized as a key role of local government and, according to the European Statistics Institute (EUROSTAT) data, approximately 
$80 \%$ of the energy and $\mathrm{CO}_{2}$ emissions used are related to activities within urban environments. The Covenant of Mayors includes 70 cities in the Republic of Croatia.

Air protection in the Republic of Croatia is regulated by the Environmental Protection Act (Official Gazette "N.N." 80/2013, 78/15), the Law on Air Protection (Official Gazette "N.N." 130/11, 47/14), and a series of implementing regulations issued on the basis of these laws [12]. In 1992, the Republic of Croatia signed the Convention on Long-range Transboundary Air Pollution (CLRTAP). It was within the framework of the Convention that the European Monitoring and Evaluation Programme (EMEP) was adopted as well. In the Republic of Croatia, the Environment and Nature Agency, established by the Ministry of Environmental Protection and Energy, is responsible for the gathering, analyzing and presenting information on pollutant emissions in the air and for preparing environmental reports.

\section{Energy Consumption and Harmful Exhaust Gas Emissions}

Table 3 shows the energy consumption for certain branches of transport in the Republic of Croatia from 2010 to 2017 expressed in PJ (Petajoules).

Table 3 - Energy consumption in the period 2010 - 2017 by individual traffic branches [16]

\begin{tabular}{|l|c|c|c|c|c|c|c|c|}
\hline Traffic branch & 2010 & 2011 & 2012 & 2013 & 2014 & 2015 & 2016 & 2017 \\
\hline Rail traffic & 1.84 & 1.75 & 1.65 & 1.54 & 1.43 & 1.30 & 1.34 & 1.34 \\
\hline Road traffic & 77.13 & 75.17 & 74.30 & 75.17 & 74.17 & 78.37 & 80.26 & 86.37 \\
\hline Air traffic & 4.55 & 4.92 & 5.07 & 5.55 & 5.56 & 5.40 & 5.71 & 6.75 \\
\hline $\begin{array}{l}\text { Maritime \& riverine } \\
\text { transport }\end{array}$ & 1.65 & 1.65 & 1.58 & 1.79 & 1.93 & 1.84 & 1.87 & 1.98 \\
\hline $\begin{array}{l}\text { Urban public } \\
\text { transport }\end{array}$ & 1.45 & 1.41 & 1.35 & 1.36 & 1.35 & 1.35 & 1.41 & 1.46 \\
\hline Other traffic & 0.08 & 0.07 & 0.07 & 0.09 & 0.09 & 0.11 & 0.12 & 0.14 \\
\hline TOTAL & 86.80 & 85.39 & 84.02 & 85.49 & 84.53 & 88.37 & 90.71 & 98.04 \\
\hline
\end{tabular}

It can be seen from the table that during the observed period road traffic is largely in the forefront of energy consumption with an average share of approximately $90 \%$. It is noticeable that total energy consumption as well as energy consumption realized in road traffic by 2012 was in decline. The main cause of this negative trend, which began in 2008, stems from the world economic crisis, reflecting the lower need for mobility and, consequently, lower fuel consumption. In 2013, there was an increase in total energy consumption as energy consumption in road traffic, while a year later, 
it was again in decline. From 2014 to 2017, there is a continuous increase in energy consumption. Thus, total energy consumption increased from 84.53 PJ to $98.04 \mathrm{PJ}$ while energy consumption in road traffic increased from 74.17 PJ to 86.37 PJ. The highest increase was recorded in the observation closing year when an increase in total energy consumption of $8 \%$ was recorded, which was almost exclusively attributed to the increase in energy consumption in road traffic (by 7.6\%). Since the energy consumption data for urban public transport is not taken into account in the table presented, while it is predominant in the Republic of Croatia, it can be concluded that the road traffic share in energy consumption is approximately $92 \%$ on the average.

Table 3 - Registered road motor vehicles and passenger cars from 2015 to 2017 in the Republic of Croatia

\begin{tabular}{|c|c|c|c|c|c|}
\hline \multicolumn{2}{|c|}{2015} & \multicolumn{2}{c|}{2016} & \multicolumn{2}{c|}{2017} \\
\hline Total & $\begin{array}{c}\text { Passenger } \\
\text { cars }\end{array}$ & Total & $\begin{array}{c}\text { Passenger } \\
\text { cars }\end{array}$ & Total & $\begin{array}{c}\text { Passenger } \\
\text { cars }\end{array}$ \\
\hline 1929726 & 1499802 & 1996056 & 1552904 & 2056127 & 1596087 \\
\hline
\end{tabular}

Source: Authors according to [6]

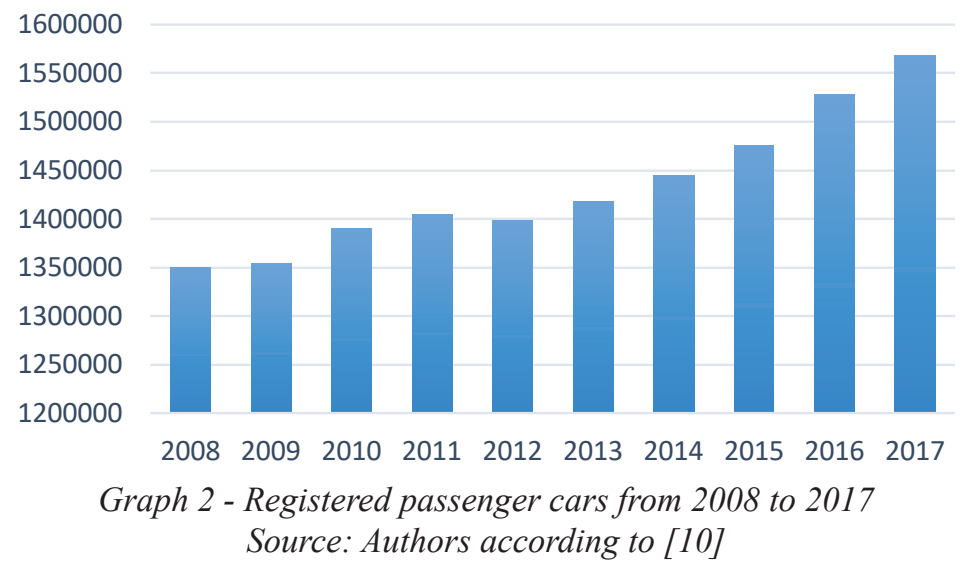

Table 3 and Graph 2 show an increase in the total number of registered road vehicles and the number of registered motor vehicles in the observed period. Thus, the number of registered passenger cars in the Republic of Croatia in 2018 amounted to 1,389,903 in 2018, whereas in 2017 there were 1,596,087 registered vehicles, which represented a $15 \%$ increase in the observed ten-year period. 


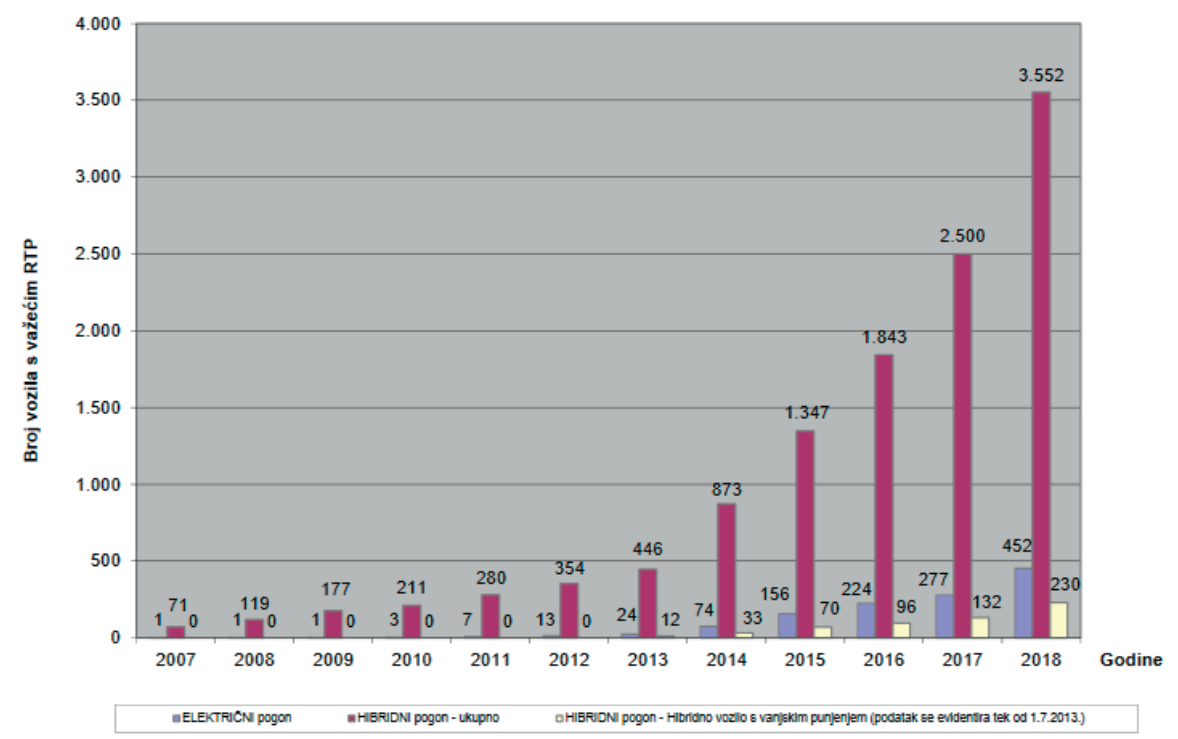

Figure 3 - Vehicle category M1 with electric and hybrid drive from 2007 to 2018 in the Republic of Croatia [10]

According to the data of the Croatian Vehicle Centre (2019), as shown in Figure 3 , the number of vehicles on electric and hybrid propulsion grew exponentially over the period from 2007 to 2018 . Thus, within the category M1 (cars and buses) in the observed period, the number of hybrid driven vehicles grew by 3,481 vehicles. In 2007, there was only one electric vehicle in the Republic of Croatia, while 10 years later their number was 452 .

\section{Implementation of ITS and Alternative Fuels in Urban Transport}

Smart mobility projects contribute to a sustainable, innovative and secure transport system, and in particular to the public transport system. The development of information and communication infrastructure significantly influences the management and organization of all types of traffic in cities, including idle traffic (parking system).

Intelligent transport systems can make a significant contribution to a more sustainable, safer and more efficient transport system and therefore the European Commission has adopted Directive 2010/40 / EC and a series of delegated regulations to accelerate the implementation of innovative transport technologies across Europe. The ITS Directive envisages the adoption of functional, technical and organizational specifications with the aim of ensuring compatibility, interoperability and continuity 
of the implementation and operational use of multimodal pre-travel and travel information services at EU level [18].

While intelligent transport systems have a remarkable potential for implementation, it should be noted that many such systems are only perceived as concepts, with technology and usage standards not yet fully developed. Systems that are used in traffic being interactive by their nature, they require data sending and receiving to be accurate and time-adjusted. The high-quality application of intelligent transport systems is based on compatibility, i.e. the ability to integrate individual telematics solutions into complex systems, applications and services [19].

Intelligent road can generally be defined as a management and informationcommunication upgrade of classical roads, providing better information for drivers, traffic management, security applications, etc. Parallel with the infrastructure, intelligent vehicles are also developed with features that significantly contribute to security, efficiency and driving comfort. In order for a technology to meet the requirement of a traffic system's sustainability, it must be included in existing traffic equipment and must be used frequently. Such devices should also play a role in facilitating economic growth and development and at all times be available, safe and reliable [19].

In the development and introduction of ITS in the Republic of Croatia over the past period, the program of motorway construction was of special importance. Croatian motorways are among the most modern and safest in Europe, as a consequence of the ITS technology applied, especially in the traffic management and tunnel incident management systems. These systems have been awarded a number of recognitions such as EUROTAP. EuroTAP (European Tunnel Assessment Program) is one of a total of eight research projects on traffic safety in tunnels. This research is directly linked to raising the level of road safety and is based on the European Directive 2004/54 / EC on tunnel safety [22].

The Republic of Croatia should, in accordance with the ITS Directive, define the strategy for establishing a national access point for providing information on multimodal travel and exchange of traffic information on the TEN-T network and urban hubs. The goal of the umbrella system is to provide access to static information and information available from public and private stakeholders (service providers) as well as access to dynamic information, if any. Integration of traffic flows into the traffic system would enable the exchange of relevant information by providing all defined technical prerequisites and creating added value for passengers within the Republic of Croatia and the EU.

Renewable energy sources contribute to reducing dependence on energy imports by ensuring sustainable energy supply security and thus contributing to the overall sustainable development strategy.

Exponential growth of lightweight road vehicles and passenger cars over the past two decades, the limitation of fossil fuels for traffic and the increase of adverse 
environmental effects have led to the need for alternative fuels. Despite the growth in the use of electric and hybrid cars, hybrid vehicles represent a temporary solution for reducing fossil fuel consumption until the improvement of hydrogen application technology as a fuel for the future. Furthermore, the European Commission highlights three types of alternative fuels for road transport, the most significant being: biofuels, natural gas and hydrogen.

Biofuels denote liquid or gas fuel produced from biomass for transport purposes. They can be produced indirectly from domestic, commercial, agricultural and industrial waste or directly from plants. Depending on the mode of production, there are several types of biofuels classified in two generations. The first generation of biofuels (ethanol, biodiesel, biogas) uses starch, sugar, animal fat and vegetable oils for its production, while forest and agricultural waste are used by the second generation, (biohydrogen, bio-dme, biomethanol, dmf, htu diesel fischer-tropsch diesel, alcohol mixture) [20].

Natural gas is mainly composed of methane and its combustion releases less carbon dioxide than oil i.e. up to $50 \%$, and by $40 \%$ less nitrogen oxide. An important difference compared to oil is that natural gas does not release heavy metals, sulphur or ashes into the atmosphere. All stocks of this gas are still unknown, but those found certainly outperform well-known oil stocks. Therefore, by shifting to natural gas, the dependence of the transport industry on oil would be attributed to history [21].

Hydrogen is an energy-charged fuel, completely clean and highly adaptable, what makes it a fuel with great potential. Its energy can be obtained with the help of fuel cells that generate energy in controlled conditions by chemical reaction of firedamp directly from the hydrogen (fuel) and oxygen.

In compliance with the Directive on the Establishment of an Alternative Fuel Infrastructure, the Law on the Establishment of an Alternative Fuel Infrastructure and the Draft National Policy Framework (NPF), the Ministry of Environmental Protection and Energy of the Republic of Croatia has defined a measure for the development of infrastructure for alternative fuels related to the construction of electric car chargers [16].

According to the available data, there are 272 publicly available charging stations recorded in the Republic of Croatia with a total of 693 connections [20]. The HEP currently has 65 high-speed charging stations with a minimum of $22 \mathrm{kWh}$ and plans to build additional stations in compliance with the Strategy 2020, whereby there are envisaged 345 charging stations to be located on motorways, in cities and villages along all state and county roads. The proposal on the number of chargers and plugs is based on a low power transmission capacity scenario on the public charging station network to cover the minimum requirements for the operation of electro-mobility. According to the mentioned measure, it is necessary to provide at least 296 plug-in points by 2020 (222 AC of minimum power 22 / (11) kW, $74 \mathrm{DC}$ of minimum power $50 \mathrm{~kW}$ ) to 164 . As can be concluded, the measure is being successfully implemented 
and despite substantial initial investments it will result, in the long run, in large energy savings, especially if the number of electric and hybrid vehicles is increased in urban and suburban public passenger transport.

\section{Conclusion}

The continual growth of the world economy imposes an increasing need to improve the transport system. The essential basis of each country in this segment is the good linking of the territory to satisfy the social, economic and environmental needs, while minimizing the negative impact on the environment, economy and society.

Traffic in urban areas, beside contributing to a number of positive effects for the development of cities, is also declared to be the leading unfavourable factor since it affects road traffic jams, reduced traffic safety, traffic noise, limited availability and mobility, and environmental and air pollution. Although motor vehicle driving technology is constantly evolving and alternative fuels are increasingly being used, emissions of harmful exhaust gases are constantly increasing, imposing new requirements, goals and legislative rules for environmental protection.

The use of intelligent transport systems in urban traffic contributes to increasing traffic safety, reducing environmental pollution, saving time, increasing mobility and productivity, and saving financial resources both publicly and privately. Integration of information flows in urban traffic would help improve decision-making in urban traffic and urban mobility, control and management systems in urban and urban mobility decision making as well as advanced analytical solutions to increase urban traffic safety. The development of an integrated decision-support system in urban traffic and urban mobility includes all of the above-mentioned elements and is in function of a better connection of all processes, with the aim of better traffic management and sustainable mobility.

\section{Literature:}

1. Luis M. Himenez Herrero (2011) Transport and mobility: the keys to sustainability. Lychnos. (4). Available at: http://www.fgcsic.es/lychnos/en_en/articles/transport_and_mobility/[Accessed 5th March 2019]

2. https://ppp.worldbank.org/public-private-partnership/ppp-sector/transportation/urbanpassenger-transport/urban-passenger-transport/ [Accessed 15th March 2019]

3. Sindik, A., et al.: Competitive Croatia, Induction Glossary. Available at: http:// www. regionalnakonkurentnost.hr/default.aspx?id=3572 [Accessed 5th March 2019]

4. Transform, Transformation agenda for low carbon cities. Available at: http://urbantransform.ez/ about/smart-energy-city/ [Accessed 3rd March 2019]

5. Lacković Vincek, Z., Dvorski, S., Dvorski Lacković, I. (2016) Prometni sustav u funkciji održivog razvoja. Notitia. 2.

6. Statistical Yearbook of the Republic of Croatia (2018). Available at: https://www.dzs.hr/Hrv Eng/ljetopis/2018/sljh2018.pdf [Accessed 21th March 2019] 
7. Hrvatska agencija za okoliš i prirodu - HAOP. Available at: http://www.haop.hr/hr/pocetnastranica [Accessed 21th March 2019].

8. Grgić, M. , Bilas, V. (2008) Međunarodna ekonomija. Zagreb: Lares plus d.o.o.

9. Zelenika, R., Pupovac, D. (2000) Transport - čimbenik proboja začaranog kruga razvitka tranzicijskih zemalja. Ekonomski pregled, 51 (9-10).

10. Centar za vozila Hrvatske - CVH. Available at: https://www.cvh.hr/naslovnica/ [Accessed 21th March 2019]

11. Fond za zaštitu okoliša i energetsku učinkovitost - FZOEU. Available at: http://www.fzoeu.hr/ [Accessed 21th March 2019]

12. Maglić, L., Maglić, L., Vilke, S., Debelić, B. (2018). Measures for improvement of energy efficiency and reduction of $\mathrm{CO}_{2}$ emissions in road transport of the Republic of Croatia. Proceedings of the International University of Travnik, Year 7, No. 17.

13. Brozović, I., Regent, A., Grgurević, M.(2014), „Emisije stakleničkih plinova, Osobito iz prometa", Journal of the Polytechnic of Rijeka, Vol. 2 (2014), No. 1.

14. http://www.covenantofmayors.eu/ [Accessed 15th March 2019].

15. Energy in Croatia (2017) Annual Energy Report. Ministry of Environment and Energy. Available at: https://mzoe.gov.hr/o-ministarstvu-1065/djelokrug-https://mzoe.gov.hr/o-ministarstvu-1065/ djelokrug-4925/energetika/energetska-politika-iplaniranje/energija-u-hrvatskoj/5330 [Accessed 22nd March 2019]

16. Četvrti nacionalni akcijski plan energetske učinkovitosti RH za razdoblje od 2017 do 2019 (2017). Ministarstvo zaštite okoliša i energetike. Available at: https://ec.europa.eu/energy/sites/ ener/files/documents/hr_neeap_2017_hr.pdf [Accessed 1st April 2019]

17. European Commission (2010). ITS Directive. Available at: https://eurlex.europa.eu/legalcontent/ EN/TXT/PDF/?uri=CELEX:32010L0040\&rid=9[Accessed 1st April 2019]

18. Madžuka, S., Zura, M., Horvat, B., Bicanic, D., Mitsakis, E. (2013) Directives of the European Union on Intelligent Transport Systems and their Impact on the Republic of Croatia. Promet Traffic \& Transportation

19. https://novac.jutarnji.hr/aktualno/kraj-jedne-ere-do-kraja-godine-sve-elektricne-punionicenaplacivat-ce-punjenje-automobila/8827031/ [Accessed 1st April 2019]

20. https://www.izvorienergije.com/biogoriva.html [Accessed 18th May 2008]

21. Vrančić T., „Plin kao ekološki prihvatljivo gorivo“, GRAĐEVINAR, Vol.62 (2010), No.12.

22. Nacionalni program za razvoj i uvođenje inteligentnih transportnih sustava u cestovnom prometu za razdoblje od 2014. do 2018. godine (2014). Government of the Republic of Croatia 